\title{
PELAKSANAAN JUAL BELI HASIL PERTANIAN DENGAN CARA BORONGAN DITINJAU DARI FIQIH MUAMALAH DIDESA MANCON KECAMATAN WILANGAN KABUPATEN NGANJUK
}

\author{
Oleh \\ Juni Iswanto \\ Institut Agama Islam Pangeran Diponegoro Nganjuk \\ juniiswanto@iaipd-nganjuk.ac.id
}

\begin{abstract}
The current development of the era raises the model of buying and selling in bulk, for that Muslims still have to hold fast to the teachings that exist in muamalah figh so that there will be no deviation from the implementation of the sale and purchase of agricultural products in bulk. Selling agricultural products in this wholesale way is the choice of farmers because there are not many risks. For example, farmers will get a profit earlier than waiting until harvest, which later can be rotated for other needs. In addition, by way of wholesale, farmers do not need to seek energy for the harvest process. Therefore, in this study want to know how the implementation of the sale and purchase of agricultural products in a wholesale way in the village of Mancon, Wilangan Subdistrict, Nganjuk Regency in terms of Muamalah Fiqh. The type of research used in this study is descriptive research. Descriptive research is research that seeks to describe and interpret existing data, in addition descriptive research is limited to efforts to express a problem or in the circumstances or events as they are, so that it is merely expressing facts (fact finding).
\end{abstract}

Keywords: Buying and Selling, sell wholesale, Muamalah Fiqh

\begin{abstract}
Abstrak
Arus perkembangan zaman memunculkan model jual beli secara borongan, untuk itu umat islam tetap harus berpegang teguh dengan ajaran yang ada dalam fiqih muamalah agar tidak terjadi penyimpangan terhadap pelaksanaan jual beli hasil pertanian secara borongan. Menjual hasil pertanian dengan cara borongan ini menjadi pilihan petani karena tidak banyak resiko. Misalnya, petani akan
\end{abstract}


medapatkan keuntungan lebih awal daripada menunggu sampai panen yang nantinya uang dapat diputar untuk kebutuhan lainnya. Selain itu, dengan cara borongan tersebut petani tidak perlu mencari tenaga untuk proses panen. Oleh sebab itu, dalam penelitian ini ingin mengetahui bagaimana pelaksanaan jual beli hasil pertanian dengan cara borongan di desa Mancon Kecamatan Wilangan Kabupaten Nganjuk ditinjau dari Fiqih Muamalah. Jenis penelitian yang digunakan dalam penelitian ini adalah penelitian deskriptif. Penelitian deskriptif merupakan penelitian yang berusaha mendeskripsikan dan menginterpretasikan data yang ada, di samping itu penelitian deskriptif terbatas pada usaha mengungkapkan suatu masalah atau dalam keadaan ataupun peristiwa sebagaimana adanya, sehingga bersifat sekedar mengungkapkan fakta (fact finding).

Kata Kunci: Jual Beli, Jual Borongan, Fiqih Muamalah

\section{Pendahuluan}

Manusia sebagai makhluk sosialtidak dapat hidup sendiri, artinya bahwa manusia selalu berhubungan dan membutuhkan orang lain. Salah satunya yaitu dalam bidang muamalah. Dalam hal muamalah, Islam telah memberikan ketentuan-ketentuan atau kaidahkaidah yang harus ditaati dan dilaksanakan, sehingga pelaksanaan muamalah harus sesuai dengan ketentuan yang sudah ditetapkan oleh syari'at Islam. Jual beli dalam Islam hukumnya adalah boleh berdasarkan dalil-dalil Al-Quran dan sunah serta ijma. ${ }^{20}$ Hal ini berdasarkan ayat yang menjelaskan tentang jual beli yang berbunyi:

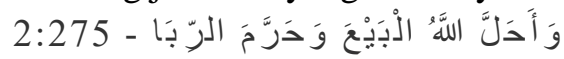

Artinya :

"Dan Allah menghalalkan jual beli dan mengharamkan riba" (QS Al-Baqarah: 275). ${ }^{21}$

Sesungguhnya praktek jualbeli itu telah ada lebih dahulu sebelum adanya konsepsi tentang muamalah (ekonomi Islam), sebab usaha manusia dalam bentuk perdagangan untuk memenuhi kebutuhan

${ }^{20}$ WahbahAz-Zuhaili, Fiqih Islam 5 Wa Adillatuhu.Jakarta: Gema Insani, 2011, 26.

${ }^{21}$ KemenagRI, Al-Qur'an danTerjemahnya, Cet.2, Semarang: PT. Toha Putra, 2013, 96. 
kehidupan manusia telah ada semenjak manusia itu ada, baik berupa tukar menukar barang (barter), jual-beli maupun kegiatan muamalah yang lain berkembang sesuai dengan perkembangan budaya manusia, akhirnya timbullah pikiran-pikiran untuk menerapkan kaidah-kaidah dasar tentang muamalah (ekonomi Islam).

Allah SWT telah menjadikan harta sebagai salah satusebab tegaknya kemaslahatan manusia didunia, untuk mewujudkan kemaslahatan tersebut, Allah SWT telah mensyariatkan cara perdagangan (jual-beli) tertentu, sebab apa saja yang dibutuhkan oleh setiap orang tidak dengan mudah diwujudkan setiap saat, dan karena mendapatkannya dengan menggunakan kekerasan dan penindasan itu merupakan tindakan yang merusak, maka harus ada cara yang memungkinkan tiap orang untuk mendapatkan apa saja yang dia butuhkan, tanpa harus menggunakan kekerasan dan penindasan, itulah perdagangan dan hukum-hukum jual-beli yang dibenarkan atau yang disyari'atkan. ${ }^{22}$ Pelaksanaan perdagangan (jual-beli) selain ada penjual, pembeli, juga harus sesuai dengan syarat rukun jual-beli, dan yang paling penting yaitu tidak adanya unsur penipuaan, jadi harus suka sama suka atau saling ridha.

Seiring dengan perkembangan zaman, muncul berbagai macam model jual beli, salah satunya adalah jual beli dengan borongan. Jual beli dengan borongan adalah ketika tanaman belum dipetik, tanaman yang akan dibeli masih dalam keadaan hidup. Sebenarnya dalam ajaran agama Islam tidak mengajarkan jual beli dengan borongan dikhawatirkan adanya ketidakjelasan dalam proses jual beli yang dilakukan. Misalnya pihak penjual atau pembeli samasama tidak mengetahuijumlah pasti tanaman yang dibeli. Mereka hanya menggunakan perkiraan yang berupa taksiran dan tidak adanya proses penakaran yang sempurna, sehingga akan menimbulkan ketidakjelasan dalam jual beli yang dilakukan. Dengan demikian bisa saja dari pihak pembeli atau penjual mendapatkan keuntungan atau mengalami kerugian.

${ }^{22}$ Taqyuddin An-Nabhani, Membangun Sistem Ekonomi Alternatif Perspekti Islam, cet. 3, Surabaya: Risalah Gusti, 2013, 149. 
Di desa Mancon Kecamatan Wilangan umumnya masyarakat dalam berdagang atau jual beli hasil pertanian menggunakan borongan. Salah satu hasil pertanian yang biasa diperjual belikan dengan borongan adalah bawang merah, padi, jagung dan sebagainya. Dalam ajaran Agama Islam, jual beli dengan tebas belum ada hadis yang menjelaskannya, tetapi aturan mengenai jual beli yang baik dan benar semuanya terangkum dalam Hukum Islam.Adanya ketidakjelasan dalam prosesnya, pihak penjual maupun pembeli samasama tidak mengetahui jumlah pasti tanaman yang akan dijual, sehingga akan memberikan keuntungan atau kerugian untuk salah satu pihak baik penjual maupun pembeli. Hal inilah yang membuat peneliti ingin mengetahui bagaimana pelaksanaan dan dampak dari jual beli hasil pertanian secara borongan di Desa Mancon Kecamatan Wilangan Kabupaten Nganjuk.

\section{Metode Penelitian}

Metode penelitian yang digunakan pada studi ini adalah metode kualitatif. Metode kualitatif sebagai prosedur penelitian yang menghasilkan data deskriptif berupa kata-kata tertulis atau lisan dari orang-orang atau perilaku yang dapat diamati. Metode kualitatif ini digunakan karena beberapa pertimbangan yaitu metode kualitatif lebih bisa dan mudah menyesuaikan apabila berhadapan dengan kenyataan ganda, metode ini menyajikan hakekat hubungan antara peneliti dan informansecara langsung dan metode ini lebih peka sehingga dapat menyesuaikan diri dan banyak penajaman pengaruh bersama terhadap pola-pola nilai yang dihadapi peneliti. ${ }^{23}$

Penerapan pendekatan kualitatif dengan pertimbangan kemungkinan data yang diperoleh di lapangan berupa data dalam bentuk fakta yang perlu adanya analisis secara mendalam. Maka pendekatan kualitatif akan lebih mendorong pada pencapaian data yang bersifat lebih mendalam terutama dengan keterlibatan peneliti sendiri di lapangan. Dalam penelitian kualitatif, peneliti menjadi

${ }^{23}$ Ahmad Tanzeh dan Suyitno, Dasar-dasar Penelitian, Cet 3, Surabaya: Elkaf, 2011, 116 
instrument utama dalam mengumpulkan data yang dapat berhubungan langsung dengan instrument atau objek penelitian. ${ }^{24}$ Dalam penelitian ini peneliti berusaha mengetahui dan mendeskripsikan dengan jelas tentang tinjauan fiqih muamalah terhadap pelaksanaan jual-beli hasil pertanian dengan cara borongan di Desa Mancon Kecamatan Wilangan Kabupaten Nganjuk.

Penelitian ini jika dilihat dari lokasi sumber datanya termasuk kategori penelitian lapangan (field research). Penelitian lapangan adalah untuk mencari di mana peristiwa-peristiwa yang menjadi objek penelitian berlangsung, sehingga mendapatkan informasi langsungdan terbaru tentang masalah yang berkenaan, sekaligus sebagai cross checking terhadap bahan-bahan yang telah ada. Ditinjau dari segi sifat-sifat data maka termasuk dalam penelitian Kualitatif yaitu penelitian yang bermaksud untuk memahami fenomena tentang apa yang dialami oleh subyek penelitian misalnya perilaku, persepsi, motivasi, tindakan dan lain-lain secara holistik, dan dengan cara deskripsi dalam bentuk kata-kata dan bahasa, pada suatu konteks khusus yang alamiah dan dengan memanfaatkan berbagai metode alamiah.

\section{Teori Dan Pembahasan}

\section{Sekilas Tentang Jual Beli}

Salah satu transaksi ekonomi yang berkembang dewasa ini dan berlangsung memenuhi kebutuhan manusia adalah jual beli. Kegiatan jual beli berlangsung sejak kehadiran manusia walaupun masih dalam bentuk sederhana. Pada mulanya jual beli hanya secara barter, yakni penukaran barang dengan barang, dan perkembangan selanjutnya berlangsung antara pnjual dan pembeli dengan penukaran barang dengan sesuatu yang disimbolkan yang dipandang memiliki nilai. ${ }^{25}$ Dalam Al-qur'an terdapat al-bai' yang direlevankan dengan

${ }^{24}$ Sugiyono, Memahami Penelitian Kualitatif, Bandung: CV Alfabeta, 2015, 2

${ }^{25}$ Muhammad Syarif chaudhry, Fundamental of Islamic Economic System,terj. Suherman Rosyidi,Sistem Economi Islam:Prinsip Dasar, Jakarta:Kencana Predana Group,2012, 113 
jual beli. Al-bai' tampaknya sebagai kegiatan transaksi tidak hanya dipandang oleh Al-Qur'an sebagai kegiatan ekonomi semata, tetapi syarat dengan dimensi lain. Teori jual beli dalam hokum islam mengajarkan setiap pemeluknya untuk selalu berusaha mencari karunia Allah dengan bermuamalat secara jujur dan benar, dan jual beli merupakan muamalat yang dihalalkan Allah SWT. ${ }^{26}$

Jual beli merupakan bagian dari ta'awun (saling tolong menolong). Bagi pembeli menolong penjual yang membutuhkan uang(keuntungan), sedangkan bagi penjual juga berarti menolong pembeli yang sedang membutuhkan barang. Karenanya jual beli itu merupakan kegiatan yang mulia dan pelakunya mendapatkan keridhoan Allah SWT. Bahkan Rasulullah saw. menegaskan bahwa penjual yang jujur dan benar, kelak diakhirat akan ditempatkan bersama Nabi, syuhada dan rang-orang yang saleh. ${ }^{27}$

Sebelum membahas lebih dalam tentang jual beli, ada baiknya diketahui terlebih dahulu pengertian jual beli. Jual beli atau dalam bahasa arab biasa disebut dengan al-bai'.Menurut Etimologi adalah tukar menukar sesuatu dengan sesuatu yang lain (muaqabalatusyai'in bin syai'in). ${ }^{28}$ Dia termasuk kata benda berlawananan, yaitu kata yang diartikan sesuatu dan lawan katanya, seperti Syira' membeli. ${ }^{29}$ Sayid sabiq mengartikan jual beli (al-bai') sebagai tukar menukar secara mutlak. Pengertian tersebut dapat di fahami bahwa jual beli menurut bahasa adalah tukar menukar apa saja, baik barang dengan barang, barang dengan uang, atau uang dengan uang. ${ }^{30}$

Dalam pengertian istilah syara' terdapat beberapa definisi yang dikemukakan oleh ulama madzhab, diantaranya; menurut ulama

\footnotetext{
${ }^{26}$ Hamzah Hasan Khariyah, Fiqih Iqtishad:Ekonomi Islam:Kerangka Dasar, Study tokoh, dan Kelembagaan Ekonomi, Makassar: Alauddin University Press, 2013, 139.

${ }^{27}$ Abdullah Rahman Ghazaly,dkk, Fiqh Muamalat , cet.2, Jakarta:KencanaPrenada Media Group, 2012, 89. Syariah,2011, 8 .

${ }^{28}$ Ahmad Sarwat, Kitab Muamalat, cet.2, tkp, Kampus

${ }^{29}$ Nasrun Haroen, Fiqih Muamalah, tkp, tpn, tt. tt., 239.

${ }^{30}$ Imam Taqyuddin, Kifayatul Akhyar, Juz I,Bandung : Al-Ma'arif,
} 
Hanafiyah, menyatakan bahwa jual beli memiliki dua arti, yaitu arti khusus dan arti umum. Arti khusus yaitu jual beli adalah tukar menukar benda dengan dua mata uang (emas dan perak) dan semacamnya.atau tukar menukar barang dengan uang atau semacamnya menurutcara yang khusus.Sedangkan arti secara umum yaitu, jual beli adalah tukar-menukar harta dengan harta menurut cara yang khusus,harta mencakup zat(barang) atau uang. ${ }^{31}$

Jual beli menurut ulama' malikiyah sebagaimana dikutip dalam bukunya Hendi Suhendi yag berjudul Fiqh Muamalah ada dua macam, yaitu jual beli yang bersifat umum dan jual beli yang bersifat khusus. Jual beli dalam arti umum ialah suatu perikatan tukar menukar sesuatu yang bukan kemanfaatan dan kenikmatan. Perikatan adalah akad yang mengikat kedua belah pihak. Tukar menukar yaitu salah satu pihak menyerahkan ganti penukaran atas sesuatu yang ditukarkan oleh pihak lain. Sesuatu yang bukan manfaat adalah bahwa benda yang ditukarkan adalah bukan dzat, Ia berfungsi sebagai objek penjualan, jadi bukan manfaatnya atau hasilnya. Jual beli dalam arti khusus adalah ikatan tukar menukar sesuatu yang bukan kemanfaatan dan bukan pula kelezatan yang mempunyai daya tarik,penukarannya bukan mas dan juga bukan perak, bendanya realisir da nada seketika,tidak merupakan utang baik barang itu ada dihadapan pembeli ataupun tidak, barang-barang yang sudah diketahui sifatsifatnya atau sudah dikeahui terlebih dahulu. ${ }^{32}$

Menurut ulama Syafi'iyah memberikan devinisi jual beli sebagai suatu akad yang mengandung tukar-menukar harta dengan harta dengan syarat yang akan diuraikan nanti untuk memperoleh kepemilikan atas benda atau manfaat untuk waktu selamanya. ${ }^{33}$ Menurut ulama Hanabilah memberikan pengertian jual beli sebagai tukar menukar harta dengan harta, atau tukar menukar manfaat yang

\footnotetext{
${ }^{31}$ Imam Taqyuddin, Kifayatul Akhyar, Juz I,Bandung : Al-Ma'arif, tt., 239

${ }^{33}$ Imam Taqyuddin, Kifayatul Akhyar, Juz I, Bandung : Al-Ma'arif, tt., 239
} 
mubah dengan manfaat yang mubah untuk waktu selamanya, bukan riba dan bukan utang.

Devinisi yang dikemukakan oleh para ulama mazhab tersebut dapat diambil intisari bahwa Jual beli adalah akad Mu'awdhah, yakni akad yang dilakukan oleh dua pihak, diamana pihak pertama menyerahkan barang dan pihak kedua menyerahkan imbalan, baik berupa uang maupun barang. Sedangkan Syafi'iyah dan Hanabilah mengemukakan bahwa objek jual beli bukan hanya barang (benda), tetapi juga manfaat, dengan syarat tukar-menukar berlaku selamanya, bukan untuk sementara. Dengan demikian ijarah (sewa-menyewa) tidak termasuk jual beli karena manfaat digunakan untuk sementara, yaitu selama waktu yang ditetapkan dalam perjanjian. Demikian ijarah yang dilakukan timbal-balik (saling pinjam), tidak termasuk jual beli, karena pemanfaatannya hanya berlaku sementara waktu. Secara umum jual beli dapat didefisinikan sebagai menukar barang dengan barang atau menukar barang dengan uang, yaitu dengan jalan melepaskan hak kepemilikan dari yang satu kepada yang lain atas dasar saling merelakan.

\section{Jual Beli Cara Tebasan atau Borongan}

Jual beli adalah kegiatan saling menukar harta dengan harta dalam bentuk pemindahan barang kepemilikan. Jual beli harus mengandung unsur muawwadhoh yang berarti tukar menukar sesuatu yang bersifat materi, sehingga jual beli hanya bisa berlaku untuk benda yang dapat ditukarkan. Istilah jual beli dengan sistem tebasan memang belum dikenal pada zaman Imam Syafi'i. Namun dalam kitab al-Umm pada bab jual beli dibahas mengenai penjualan buah yang masih berada di pohonnya. Mengenai jual beli buah yang masih berada di pohonnya ini, Imam Syafi'i berpendapat:

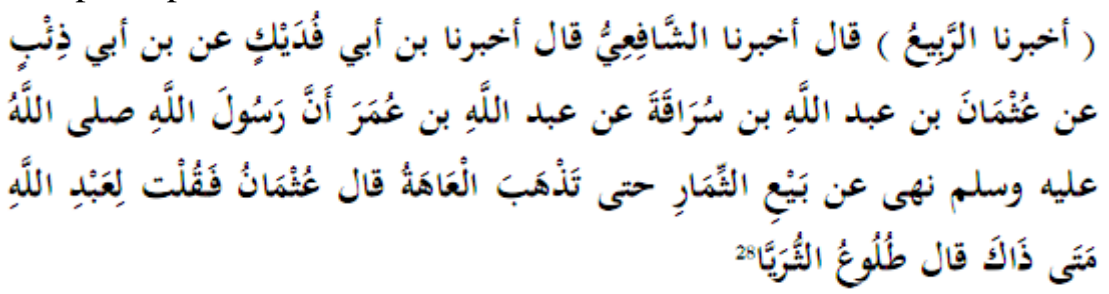


Artinya :

'Dikabarkan kepada kami oleh ar-Rabi' yang mengatakan: dikabarkan kepada kami oleh Asy-Syafi'i yang mengatakan: dikabarkan kepada kami oleh Ibnu Abi Fudaik, dari Ibnu Abi Dzi'b, Dari Usman bin Abdullah bin Saraqah, dari Abdullah bin Umar, bahwa Rasulullah SAW melarang menjual buah-buahan sehingga hilanglah penyakitnya. Kata Usman: ,lalu saya bertanya kepada Abdullah: Kapan yang demikian itu?: Abdullah menjawab: tampak buah-buahnya: "34

Imam Syafi'i melalui hadis tersebut, ingin menegaskan bahwasannya syarat kebolehan penjualan buah yang masih berada di pohonnya adalahnya tampak buahnya. Buah yang akan dijual bisa dilihat bentuknya. Tidak diperkenankan menjual buah yang masih belum ada bentuknya karena hal itu dikhawatirkan akan menjurus pada penipuan dalam proses jual-beli. Selain itu menjual buah yang belum ada wujudnya juga tidak bisa dipastikan tumbuhnya buah karenakemungkinan adanya penyakit yang menyerang pohon sehingga buahnya tidak bisa nampak. Selain keharusan adanya ketampakan buah, ukuran buah juga menjadi pertimbangan dalam penjualan buah yang masih berada di pohonnya. Dalam hal ini, Imam Syafi'i berpendapat:

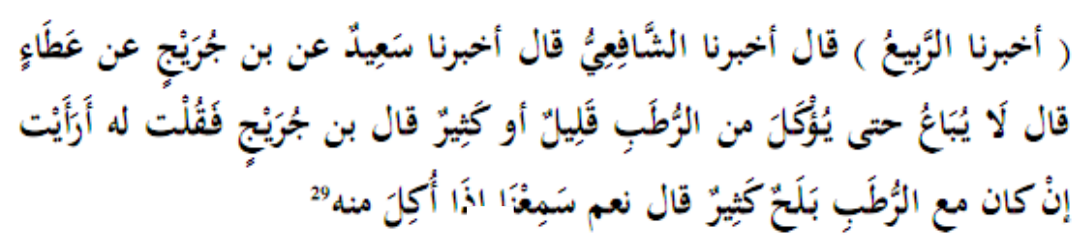

Artinya :

'Dikabarkan kepada kami oleh Ar-Rabi' yang mengatakan: dikabarkan kepada kami oleh Asy-Syafi'i yang mengatakan: dikabarkan kepada kami oleh Said dari Ibnu Juraij, dari Atha' yang mengatakan: ,tidak dijual sehingga dapat dimakan dari ruthab

${ }^{34}$ Abi Abdillah Muhammad bin Idris al-Syafi'i, al-Umm, Kitab Jual-Beli juz IVBeirut: Dar al-Ma'rifah, tt. 47. 
(kurma), yang sedikit atau banyak: Kata Ibnu Juraij: lalu saya bertanya kepada Atha': 'apakah pendapat anda kalau ada bersama ruthab itu banyak kurma muda?. Beliau menjawab: ya! Kami mendengar apabila dapat dimakan dari kurma muda : ",35

Hadis tersebut di atas menjelaskan bahwa buah yang masih berada di atas pohon bisa untuk diperjualbelikan tidak hanya buah yang sudah masak tapi juga buah yang masih muda. Lebih lanjut, buah muda yang bisa diperjualbelikan adalah buah yang belum masak namun bisa dimakan. Artinya, tidak diperbolehkan buah yang kecil dan belum masak untuk diperjualbelikan karena belum dapat diambil manfaatnya.

Jual beli dengan sistem tebasan sebenarnya memiliki kesamaan dengan sistem jual beli salam/salaf dalam hukum Islam. Sebagaimana diketahui, salam adalah jual beli dengan cara ditangguhkan penyerahan barangnya pada waktu tertentu yang telah disepakati oleh penjual danpembeli saat akad jual beli dilakukan. Sebagaimana Imam Syafi'i berpendapat:

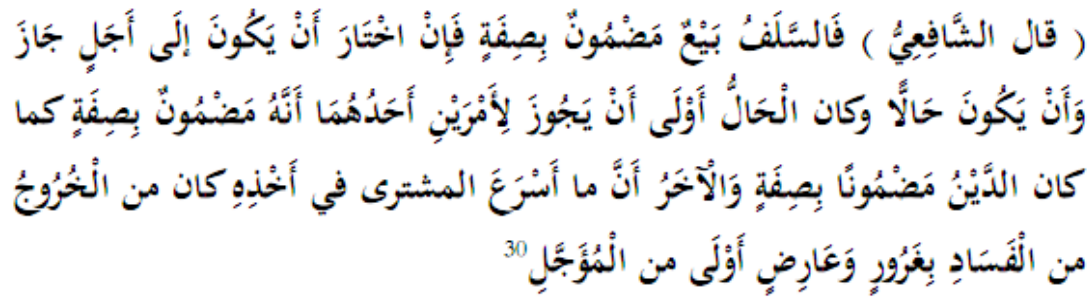

Artinya :

"Imam Syafi'i berkata: Salaf (salam) itu adalah penjualan yang dijamin dengan sifat. Kalau ia memilih bahwa penjualan salaf itu sampai kepada suatu waktu, maka boleh. Dan bahwa bahwa ada salaf itu penjualannya tunai. Dan adalah tunai itu lebih utama bahwa ia boleh karena dua perkara. Salah satu dari dua perkara itu dijamin dengan sifat. Sebagaimana adanya hutang itu dijamin dengan sifat. Perkara yang lain (kedua), bahwa apa yang

${ }^{35}$ Ibid. 48. 
disegerakan oleh pembeli pada mengambilnya adalah termasuk dalam keluar dari kebatalan dengan penipuan dan halangan, yang lebih utama daripada ditangguhkan. ${ }^{, 36}$

Penjelasan di atas mengisyaratkan bahwa jual beli salam itu adalah penjualan dengan dua sifat. Dimana mekanismenya bisa dilakukan dengan ditangguhkan atau dilakukan dengan tunai. Penjualan yang ditangguhkan penyerahan barangnya tidak akan mengurangi manfaat barang yang ditangguhkan. Namun apabila penjualan itu dilakukan dengan penyerahan langsung barangnya setelah akad, hal itu lebih utama demi menghindari terjadinya penipuan dan mengurangi resiko kerusakan barang akibat halangan yang tidak terduga seperti adanya penyakit yang tiba-tiba menyerang dan merusak buah yang diperjualbelikan.

\section{Pelaksanaan Jual Beli Hasil Pertanian Dengan Cara Borongan}

Berdasarkan hasil temuan penelitian pelaksanaan jual beli hasil pertanian di Desa Mancon Kecamatan Wilangan Kabupaten Nganjuk berawal dari seorang petani yang ingin menjual hasil panennya dan dia tidak ingin repot-repot mengeluarkan banyak uang untuk memanennya, kemudian pemborong mendatangi petani di sawahnya yang ingin membeli hasil panennya, dan membelinya secara keseluruhan yang kemudian dinamakan borongan.

Jual beli hasil pertanian yang dilakukan dengan cara borongan untuk menghemat biaya yang biasanya pelaksanaan akad jual beli dilakukan di rumah petani, biasanya pemborong sudah melihat tanaman di ladang sehingga dapat memastikan harga dalam melakukan tawar menawar. Sistem jual beli hasil pertanian dengan cara borongan terjadi ketika seorang petani tidak ingin repot-repot memanen hasil pertaniannya. Apabila hasil pertanian sudah ada yang membeli, petani tidak perlu mencari buruh untuk memanen hasil panennya, pemborong lebih memilih membeli hasil tanaman dengan

\footnotetext{
${ }^{36}$ Ibid., 97.
} 
sistem borongan karena membeli secara borongan dapat menghasilkan keuntungan yang cukup besar.

Hal ini sesuai menurut Sayyid Sabiq jual beli adalah tukarmenukar harta dengan harta yang lain dengan jalan saling rela atau pemindahan hak milik dengan sesuatu ganti atas dasar kerelaan. ${ }^{37} \mathrm{Jual}$ beli adalah suatu proses di mana seseorang penjual menyerahkan barangnya kepada pembeli (orang lain) setelah mendapatkan persetujuan mengenai barang tersebut, yang kemudian barang tersebut diterima oleh si pembeli dari si penjual sebagai imbalan uang yang diserahkan. Dengan demikian secara otomatis pada proses di mana transaksi jual beli berlangsung, telah melibatkan dua pihak, di mana pihak yang satu menyerahkan uang (harga) sebagai pembayaran barang yang diterimanya dan pihak yang lain menyerahkan barangnya sebagai ganti dari uang yang telah diterimanya, dan proses tersebut dilakukan atas dasar rela sama rela antara kedua pihak, artinya tidak ada unsur keterpaksaan atau pemaksaan pada keduanya.

Pendapat tersebut diperkuat dengan rukun jual beli terdiri dari tiga macam yaitu:

1) Orang-orang yang berakad (Penjual dan Pembeli).

Sighat (aqad) dari dua belah pihak, yakni perikatan atau kesepakatan pemilikan yang diperoleh melalui transaksi jual beli, tukar-menukar barang, hibah dan sebagainya. ${ }^{38}$ Sedangkan pengertian aqad menurut fuqaha adalah Perikatan adalah ijab dan qabul (serah terima) menurut bentuk yang disyari'atkan agama, nampak bekasnya pada yang diaqadkan itu. ${ }^{39}$ Akad jual beli dapat dilakukan dalam segala macam pernyataan, asalkan dapat dipahami maksudnya oleh kedua belah pihak yang melakukan aqad, baik dalam bentuk perkataan, perbuatan maupun isyarat bagi yang bisu atau berupa tulisan bagi yang jauh, bisa juga dapat dilakukan melalui kinayah.

37 Sayyid Sabiq, Fiqh Sunnah, diterj. Nur Hasanuddin, cet. 2, Jakarta: Pena Pundi Aksara, 2012, 126.

${ }^{38}$ H. Hamzah Ya'qub, Kode Etik Dagang Menurut Islam, cet.3, Bandung : Diponegoro, 2014, 71.

${ }^{39}$ Ibid., 171 
2) Ma'qud alayh (benda atau barang yang menjadi obyek akad)

Adanya Ma'qud 'alaih yaitu barang yang dijadikan obyek dari jual beli itu sendiri. Sebelum penulis simpulkan beberapa persyaratan yang harus dipenuhi pada saat jual beli dilangsungkan, maka tidak ada salahnya penulis kemukakan beberapa persyaratan yang harus dipenuhi pada saat transaksi dilangsungkan, sehingga jual beli tersebut dinyatakan sah dan boleh menurut syara'.

3) 'Aqd (Ijab Qabul)

Rukun jual beli termasuk diantaranya adalah adanya akid, dalam hal ini yang dimaksud adalah penjual dan pembeli atau dengan bahasa lain jual beli tidak akan terlaksana kalau tidak ada keduanya. ${ }^{40}$

Syarat jual beli yang sesuai dengan rukun jual beli adalah sebagai berikut:

1) Syarat orang-orang yang berakad. Para Ulama fiqh sepakat menyatakan bahwa orang yang melakukan aqad jual beli harus memenuhi syarat:

a) Berakal, agar dia tidak terkicuh, orang yang gila atau bodoh tidak sah jual belinya. Adapun yang dimaksud berakal, yaitu dapat membedakan atau memilih mana yang terbaik bagi dirinya, dan apabila salah satu pihak tidak berakal maka jual beli yang diadakan tidak sah.

b) Dengan kehendaknya sendiri (bukan dipaksa), bahwa dalam melakukan perbuatan jual beli tersebut salah satu pihak tidak melakukan suatu tekanan atau paksaan kepada pihak lainnya, sehingga pihak yang lain tersebut melakukan perbuatan jual bali bukan lagi disebabkan kemauannya sendiri, tapi disebabkan adanya unsur paksaan, jual beli yang dilakukan bukan atas dasar "kehendaknya sendiri" adalah tidak sah.

c) Keduanya tidak mubaz|ir, maksudnya para pihak yang mengikatkan diri dalam perjanjian jual beli tersebut bukanlah

${ }^{40}$ Mas'ud Ibnu dan Zainal Abidin, Fiqh Mazhab Syafi'I, cet 4, Bandung: CV. Pustaka Setia, 2017, 26 
manusia yang boros (mubazir), sebab orang yang boros di dalam hukum dikategorikan sebagai orang yang tidak cakap bertindak, maksudnya dia tidak dapat melakukan sendiri suatu perbuatan hukum walaupun kepentingan hukum itu menyangkut kepentingannya sendiri.

d) Balig atau dewasa, dewasa dalam hukum Islam adalah apabila telah berumur 15 tahun, atau telah bermimpi (bagi anak lakilaki) dan haid (bagi anak perempuan), dengan demikian jual beli yang diadakan anak kecil adalah tidak sah. ${ }^{41}$

2) Syarat benda atau barang yang menjadi obyek akad. Obyek jual beli adalah benda yang menjadi sebab terjadinya perjanjian jual beli yang syarat-syaratnya adalah:

a) Suci barangnya

b) Harus bermanfaat, jual beli serangga, ular, tikus, tidak boleh kecuali untuk dimanfaatkan.

c) Milik sendiri, jika jual beli berlangsung sebelum ada izin dari pemilik barang, maka jual beli seperti ini dinamakan bay' fudul.

d) Mampu menyerahkan, bahwa yang diakadkan dapat dihitung waktu penyerahannya secara syara' dan rasa. Sesuatu yang tidak dapat dihitung pada waktu penyerahannya, tidak sah dijual, seperti ikan yang berada dalam air.

e) Diketahui, jika barang dan harga tidak diketahui atau salah satu keduanya tidak diketahui, jual beli tidak sah karena mengandung unsur penipuan.

f) Barang yang diakadkan ada di tangan, adapun menjualnya sebelum di tangan, maka tidak boleh. ${ }^{42}$

Pelaksanaan jual beli hasil pertanian dengan cara borongan sama dengan jual beli yang lain akan tetapi dalam pengambilan barangnya yang berbeda, kalau jual beli dengan cara

${ }^{41}$ Chairuman Pasaribu, Hukum Perjanjian Dalam Islam, cet. 7, Depok: Sinar Gravika, 2014, 35-36

${ }^{42}$ Sayyid Sabiq, Fiqh Sunnah, diterj. Nur Hasanuddin, cet 2, Jakarta: Pena Pundi Aksara, 2012, 49-62 
borongan ini pelaksananya dengan jalan setelah akad berlangsung tanaman yang ada di sawah sudah menjadi pemilik pembeli atau hak milik atas tanaman sudah berpindah tangan. Jadi semuanya tergantung pada pembeli, artinya pengambilan pemanenannya menjadi hak pembeli.

Jual beli (transaksi) gharar termasuk dalam kategori memakan harta dengan cara yang batil dan terlarang atau tidak termasuk jual beli (transaksi) yang diperbolehkan. Jual beli dengan cara borongan tidak termasuk gharar karena sudah sesuai dengan aturan dari syariat Islam yaitu dengan adanya penjual danpembeli yang saling rela, apabila sewaktu-waktu hasil panennya harga jual di pasar turun ataupun naik tidak ada permasalahan.

\section{Pelaksanaan Jual Beli Hasil Pertanian dengan Cara Borongan Ditinjau dari Fiqih Muamalah}

Adanya jual beli secara borongan, sedikit banyak tetap menimbulkan dampak bagi masyarakat setempat. Dari sisi perekonomian, masyarakat lebih sejahtera, karena proses pembayaran dilakukan beberapa hari sebelum panen dimulai, hal ini sangat menguntungkan bagi masyarakat, karena bisa digunakan untuk membeli bibit - bibit tanaman lagi, sehingga lahan pertanian tidak kosong tanaman dalam jangka waktu yang panjang.

Selain itu, jual beli dengan sistem borongan sangat diminati oleh warga setempat, karena sangat memudahkan terutama dalam penjualannya, tidak perlu harus kepasar untuk menjualnya, karena pembeli akan datang langsung ke sawah para petani tersebut. Ada beberapa alasan yang membuat mereka lebih menyenamgi jual beli sacara borongan, antara lain yaitu $:^{43}$

a. Berawal dari seorang petani yang ingin menjual hasil panennya dan dia tidak ingin repot-repot mengeluarkan banyak uanguntuk memanennya.

${ }^{43}$ Hasil wawancara dengan Bapak Pairan pada tanggal 24 Maret 
b. Pemborong mendatangi petani di sawahnya yang ingin membeli hasil panennya, dan membelinya dengan secara keseluruhan yang kemudian dinamakan borongan/borongan

c. Jual beli hasil pertanian yang dilakukan dengan cara boronganuntuk menghemat biaya

d. Pelaksanaan akad jual beli dilakukan di rumah petani, biasanya pemborong sudah melihat tanaman di ladang sehingga dapat memastikan harga dalammelakukantawar menawar

e. Sistem jual beli hasil pertanian dengan cara borongan terjadi ketika seorang petani tidak ingin repot-repot memanen hasil pertaniannya. Apabila hasil pertanian sudah ada yang membeli, petani tidak perlu mencari buruh untuk memanenhasil panennya

f. Pemborong lebih memilih membeli hasil tanaman dengan sistem borongan karena membeli secara borongandapat menghasilkan keuntungan yang cukup besar.

Pelaksanaan jual beli hasil pertanian dengan cara borongan ditinjau dari Fiqih Muamalah di Desa Mancon Kecamatan Wilangan KabupatenNganjuk sudah sesuai dengan aturan dari syariat Islam yaitu dengan adanya penjual danpembeli saling rela dan tidak adaperselisihan di kemudian hari. Jika ditinjau dari syarat dan rukun yang ditawarkan oleh ulama' fiqih Syafi'iyyah, sistem jual-beli hasil pertanian dengan menggunakan sistem borongandi Desa Mancon semua rukunnya dapat terpenuhi, yaitu mulai darial-'aqidain, alma'qud 'alaihdan shighat al-'aqd. Dalam al-'aqidain yakni penjual dan pembeli merupakan orang yang sudah dewasa, berakal dan memiliki kehendak sendiri dalam melakukan jual-beli. Sedangkan dalam al-ma'qud 'alaihyakni pada objek barangyang akan dijual merupakan barang yang suci, bermanfaat, barang milik sendiri dan bukan milik orang lain, dan barangnya dapat diserah terimakan. Mengenai shighat al-'aqdsendiri yakni kalimat ijab dan qabul juga sudah jelas diucapkan.

Jual beli hasil pertanian dengan cara borongan yang ada di Desa Manconjelas bukan termasuk ghararsebab barangnya dapat diserahkan dengan diserahkan pada saat awal proses transaksi (akad) jenis barang yang dijual belikan sudah ditentukan bersama, begitu 
juga dengan jenis, ciri-ciri, waktu dan penyerahannya. Namun seiring dengan perkembangan zaman dan untuk menunjukkan elastisitas hukum Islam, maka jual beli hasil pertanian dengan cara borongan di Desa Mancon diperbolehkan asalkan penjual dan pembeli saling rela dan tidak ada perselisihan dikemudian hari. Hal ini merujuk pada firman Allah dalam surat al-Nisa ayat 29 yang berbunyi:

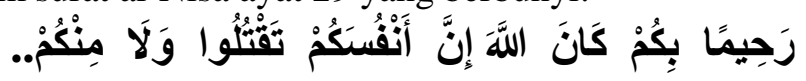

Hai orang-orang yang beriman, janganlah kamu saling memakan harta sesamamu dengan jalan yang batil, kecuali dengan jalan perniagaan yang berlaku dengan suka sama-suka di antara kamu. dan janganlah kamu membunuh dirimu; Sesungguhnya Allah adalah Maha Penyayang kepadamu. (Q.S.an-Nisa':29). ${ }^{44}$

Ayat tersebut di atas merupakan sebuah ayat yang berdimensi sangat luas dalam penerapan hak-hak konsumen. Atas dasar inilah muncul beberapa hukum-hukum fiqih muamalah yang terinci. Para ahli tafsir mengemukakan bahwa ungkapan "janganlah kamu saling memakan harta sesamamu" mengandung pengertian dimana hal itu mencakup larangan untuk mengonsumsi harta milik diri sendiri ataupun orang lain dengan cara yang bathil, dalam arti cara yang haram, cara yang tidak benar ataupun cara yang tidak dihalalkan oleh syara'.

\section{Kesimpulan}

Berdasarkan hasil penelitian mengenai tradisi praktek jual beli hasil pertanian dengan cara borongan didesa Mancon Kecamatan Wilangan Kabupaten Nganjuk, maka dapat diambil kesimpulan sebagai berikut :

1. Pelaksanaan jual beli hasil pertanian di Desa Mancon Kecamatan Wilangan Kabupaten Nganjuk mayoritas petani menjual hasil pertaniannya dengan cara borongan yang mana praktek jual beli hasil pertanian dengan menggunakan sistem borongan berawal dari seorang petani yang ingin menjual hasil panennya dan dia Putra, 2013, 122

${ }^{44}$ Kemenag RI, Al-Qur'an dan Terjemahnya, Semarang: PT. Toha 
tidak ingin repot-repot mengeluarkan banyak uang untuk memanennya dengan harapan mendapatkan keuntungan yang lebih besar dibandingkan dengan cara menjual secara eceran langsung, yang tentunya membutuhkan waktu dan tenaga yang lebih besar.

2. Pelaksanaan jual beli hasil pertanian dengan cara borongan ditinjau dari Fiqih Muamalah di Desa Mancon Kecamatan Wilangan Kabupaten Nganjuk diperbolehkan karena sudah sesuai dengan aturan dari syariat Islam yaitu dengan adanya penjual dan pembeli saling rela dan tidak ada perselisihan di kemudian hari. Jika ditinjau dari syarat dan rukun yang ditawarkan oleh ulama' fiqih Syafi'iyyah, sistem jual-beli hasil pertanian dengan menggunakan sistem tebasan di Desa Mancon semua rukunnya dapat terpenuhi, yaitu mulai dari al-'aqidain, al-ma'qud 'alaih dan shighat al-'aqd. Dalam al-'aqidain yakni penjual dan pembeli merupakan orang yang sudah dewasa, berakal dan memiliki kehendak sendiri dalam melakukan jual-beli. Sedangkan dalam alma'qud 'alaih yakni pada objek barang yang akan dijual merupakan barang yang suci, bermanfaat, barang milik sendiri dan bukan milik orang lain, dan barangnya dapat diserah terimakan. Mengenai shighat al-'aqd sendiri yakni kalimat ijab dan qabul juga sudah jelas diucapkan.

3. Pandangan masyarakat tentang pelaksanaan jual beli Hasil Pertanian dengan Cara Borongan di desa mancon Wilangan Nganjuk,

a) Berawal dari seorang petani yang ingin menjual hasil panennya dan dia tidak ingin repot-repot mengeluarkan banyak uang untuk memanennya.

b) Pemborong mendatangi petani di sawahnya yang ingin membeli hasil panennya, dan membelinya dengan secara keseluruhan yang kemudian dinamakan borongan/borongan.

c) Jual beli hasil pertanian yang dilakukan dengan cara borongan untuk menghemat biaya.

d) Pelaksanaan akad jual beli dilakukan di rumah petani, biasanya pemborong sudah melihat tanaman di ladang 
sehingga dapat memastikan harga dalam melakukan tawar menawar.

e) Sistem jual beli hasil pertanian dengan cara borongan terjadi ketika seorang petani tidak ingin repot-repot memanen hasil pertaniannya. Apabila hasil pertanian sudah ada yang membeli, petani tidak perlu mencari buruh untuk memanen hasil panennya.

f) Pemborong lebih memilih membeli hasil tanaman dengan sistem borongan karena membeli secara borongan dapat menghasilkan keuntungan yang cukup besar.

\section{Daftar Pustaka}

Al-Sarkhasi, Syamsudin. Kitab Al-Mabsut, Juz VI, Dar Al-Kutub, Beirut, tt.

Arikunto, Suharsimi, Prosedur Penelitian Suatu Pendekatan Praktek, Rineka Cipta, Jakarta, 2012

An-Nabhani, Taqyudin, Membangun Sistem Ekonomi Alternative

Perspektif Islam, cet. 3, Risalah Gusti, Surabaya, 2013.

Fathoni, Abdurrahmat., Metodologi Penelitian dan Teknik Penyusunan Skripsi, PT. Rineka Cipta,Jakarta, 2012

Hanbal, Imam Ahmad bin., Musnad Ahmad Hanbal Kitab Musnad Asy-Syamsiyin jilid II

Hasan, M. Ali., Berbagai Macam Transaksi Dalam Islam.(Fiqh Muamalat), PT Raja Grafindo Persada, Jakarta, 2011

Hendi, Suhendi, Fiqih Muamalah, Rajawali Press, Jakarta, 2014.

Kurniawan, Yudha. Tinjauan Sosiologi Hukum Islam Terhadap Praktik Jual Beli Hasil Pertanian Secara Tebasan Di Kecamatan Galur Kabupaten Kulon Progo, Fakultas Syariah dan Hukum, Yogyakarta, 2015.

Majah, Ibnu.., Sunan Ibnu Majah, Juz II , Dar Al-Fikr, Beirut, 2012 Moleong, Lexy J., Metodologi Penelitian Kualitatif, PT Remaja Rosdakarya, Bandung, 2011

Muhammad bin Idris al-Syafi'i, Abi Abdillah., al-Umm, Kitab Jual-Beli juz IV, Dar al-Ma'rifah, Beirut, tt. 
Nafiah Afiyatun, Pandangan Para Kyai Terhadap Praktek Jual Beli Cengkeh Ijon Di Desa Jurug Kecamatan Sooko Kabupaten Ponorogo, skripsi tidak diterbitkan, Program Studi Muamalah Jurusan Syariah Sekolah TinggiAgama Islam Negeri (STAIN), Ponorogo, 2014

Sabiq, Sayyid., Fiqh Sunnah, diterj. Nur Hasanuddin, Pena Pundi Aksara, Jakarta, 2012.

Sugiyono, Memahami Penelitian Kualitatif, CV Alfabet, Bandung, 2012.

Syafe'i, Rachmad, Fiqih Muamalah, CV. Pustaka Setia, Bandung, 2012.

RI, Kemenag, Al-qur'an dan terjemahnya, CV. Widya Cahaya, Bandung, 2017.

Taqyuddin, Imam. Kifayatul Akhyar, Juz I, Al-Ma'arif, Bandung,2013

Wahbah Az-Zuhaili, Fiqih Islam 5 Wa Adillatuhu, Gema Insani, Jakarta, 2011. 